\title{
Os nacionalismos nas ondas do rádio*
}

\author{
ANTÔNIO CARLOS SILVA**
}

RESUMO: Este artigo analisa a transmissão radiofônica, desde meados do século XIX até a metade do século XX. A proliferação de aparelhos de transmissão de rádio, assim como o de emissoras, logo fora percebida como importante instrumento de promoção de políticas, em diversas partes do globo. Se o rádio servia para o entretenimento, divulgando óperas, concertos, músicas regionais, também o seu potencial de propaganda política era estudado e rapidamente aplicado. A capacidade da transmissão radiofônica de ultrapassar fronteiras físicas, era vista como maneira de enfraquecer regimes adversários, mas também de integrar territórios considerados gigantescos, como o Brasil. A rádio era percebida como um poderoso instrumento de ação política.

PALAVRAS-CHAVE: Rádio, propaganda política, cultura de massas, nacionalismo.

Hoje ainda causam surpresa notícias do uso do telefone celular por detentos no sistema penitenciário que, de dentro das celas, comandam ações de organizações criminosas fora das cadeias. Ou seja: territórios (de dentro e fora dos presídios) separados fisicamente se comunicam por ondas eletromagnéticas que se propagam na atmosfera. Mas a apropriação da radiocomunicação não é tão contemporânea assim.

Na primeira metade do século $\mathrm{XX}$, principalmente a partir da criação e do desenvolvimento das emissoras de rádio na década de 1920, a programação das estações radiofônicas foi usada pelos diversos nacionalismos da época. Conseqüentemente, as ondas radiofônicas tiveram dois movimentos simultâneos.

Em alguns países, parte da programação das emissoras de rádio foi direcionada para a dominação interna via língua pátria, visando uma integração nacional pelas ondas radiofônicas. Em outras nações, ocorreu a expansão das ondas de rádio para outros territórios, com transmissões nas línguas receptoras e divulgação de propaganda política. Para entender tais processos, é conveniente recordar o nascedouro dessas tecnologias.

A partir de meados do século XIX, em diversos está-nações, cientistas fizeram experiências de radiocomunicação. Os testes visavam o registro de sons, como também a transmissão destes e de outros sinais via ondas eletromagnéticas. Parecia uma corrida 
tecnológica entre as nações. O norte-americano Samuel F. B. Morse conseguiu enviar a primeira mensagem telegráfica a longa distância em 1844. Seis anos mais tarde o alemão Daniel Ruhmkoff emitiu ondas eletromagnéticas. Em 1877, o norte-americano Thomas Alva Edison registrou som em cilindros, criando o fonógrafo.

José Ramos Tinhorão ${ }^{1}$ mostra que no Brasil o fonógrafo foi contemporâneo do processo de libertação dos escravos negros, a partir de 1888. O invento registrou ritmos musicais afro-brasileiros, como o lundu e os batuques. Ainda nas Américas, o aparelho também gravou as primeiras manifestações de jazz, one-step, tango e maxixe.

Em 1892, os sons de palavras faladas foram transmitidos e recepcionados por aparelhos, instalados na cidade paulista de Mogi das Cruzes. A experiência é de autoria do padre gaúcho Roberto Landell de Moura. Ele somente conseguiu patentear esta transmissão sem fios em 1901, cinco anos após o registro feito por Guglielmo Marconi. Oficialmente, o engenheiro italiano é considerado o pioneiro da radiocomunicação mundial.

As patentes da radiocomunicação de Marconi foram adquiridas pela empresa britânica Marconi Corporate e usadas inicialmente no setor marítimo. A iniciativa inglesa visava uma conquista internacional da nova tecnologia.

A Alemanha sediou em 1903 e 1906 duas conferências internacionais sobre transmissões via ondas de rádio. A reunião de 1906 criou a União Radiotelegráfica Internacional, que regularizou o uso das freqüências de rádio sem interferências. Contudo, prevaleceu uma regra imperialista ${ }^{2}$. O primeiro a chegar era servido. Bastava notificar à União Radiotelegráfica a intenção de utilizar uma faixa de ondas, para a nação tornar-se beneficiária do canal.

Também na Alemanha ocorreram as primeiras transmissões internacionais de programas radiofônicos de notícias, em 1913. Sete anos depois, na Holanda, as transmissões radiofônicas mesclavam noticiário econômico com informações sobre a Bolsa de Valores de Amsterdam. Ainda em 1920 os franceses passaram a vender rádios de pilha com fones de ouvido.

Depois deste aprimoramento tecnológico, pode-se dizer que houve um segundo momento da radiocomunicação. Foi durante a década de 1920, quando surgiram as primeiras emissoras de rádio que logo proliferaram. A estação KDKA, da cidade de Pittsburgh, Estado da Pensilvânia, Estados Unidos, é considerada a primeira rádio que teve uma programação regular. Em 02 de novembro de 1920 a KDKA transmitiu o 
resultado das eleições norte-americanas. Quatro anos depois, havia nos Estados Unidos, 530 estações radiofônicas funcionando.

Na área de radiocomunicação, a primazia da indústria era da Inglaterra desde o início do século XX. Mas após a Primeira Guerra Mundial (1914-1918) a liderança passou a ser dividida. Os norte-americanos criaram em 1919 a Radio Corporation of America (RCA). Era um consórcio entre mega-empresas de equipamentos elétricos e de telecomunicações: General Eletric, ATT, Westinghouse e United Fruit. As empresas norte-americanas de aparelhos de rádio começaram a expandir a fabricação de equipamentos para outros países.

A Westinghouse Eletric Company trouxe para o Brasil em 1922 três estações de rádio. Duas foram compradas pelo governo federal do presidente Epitácio Pessoa para transmissão radiotelegráfica. A terceira, de 500 watts, foi montada no Morro do Corcovado, no Rio de Janeiro. Em 07 de setembro, transmitiu, do Teatro Municipal para a Exposição do Centenário da Independência do Brasil, um discurso do presidente Epitácio e a execução da ópera $O$ Guarani, de Carlos Gomes. Esta é considerada oficialmente a primeira transmissão radiofônica do Brasil. Mas José Ramos Tinhorão aponta que em 1919, três anos antes, um grupo de jovens já havia organizado um rádioclube em Recife.

A primeira estação radiofônica brasileira, a Sociedade Rádio do Rio de Janeiro, foi fundada em 23 de abril de 1923 pelos pesquisadores Henrique Morize e Roquette Pinto, da Academia Brasileira de Ciências. Sua programação exemplifica as características radiofônicas brasileiras da década de 1920. Transmitia apresentações lítero-musicais para um público seleto que gostava de ouvir ópera e tinha condições de comprar um aparelho receptor de rádio. Os ouvintes, por vezes, emprestavam ou doavam seus discos de vinil para que as emissoras os tocassem. Também mantinham financeiramente a programação via rádio-clubes.

Datam deste período ainda as primeiras manifestações no Brasil em favor do uso das emissoras de rádio para o ensino. Em 1925, a Associação Brasileira de Educação (ABE) colocou-se à disposição do Governo de Mato Grosso para elaborar um projeto específico para que o Estado pudesse usar o rádio e o cinema, assim como em outros países, para educar os cidadãos. 
(...) No Brasil, a enorme área territorial em que se dissemina a população escassa, e a grande percentagem de adultos destituídos de cultura, até mesmo analfabetos aconselham ainda mais, a adoção generalizada, sistemática, intensiva, desses meios de difusão de ensinamentos. (....... ${ }^{3}$

A intenção da $\mathrm{ABE}$ coincidia com o propósito de Roquette Pinto e Henrique Morize: criar um sistema de transmissão da palavra à distância como um meio revolucionário de difusão de conhecimentos e cultura. Márcia Vidal Nunes considera que $o$ surgimento da radiodifusão no Brasil, na década de 20, foi marcado pelo projeto de Roquette Pinto de “educar as massas”, integrando-as através do rádio. ${ }^{4}$

Em 1931, após o golpe de Estado de 1930 e já no Governo Provisório, Getúlio Vargas assinou em 27 de maio, o decreto-federal nº 20.047 que regulou a execução dos serviços de radiocomunicações no território nacional. O caput do artigo 12 deste decreto determina que "o serviço de radiodifusão é considerado de interesse nacional e de finalidade educacional”.

O primeiro parágrafo do mesmo artigo anuncia que "o Governo da União promoverá a unificação dos serviços de radiodifusão, no sentido de constituir uma rede nacional que atenda aos objetivos de tais serviços”. E o quarto parágrafo estabelece que “as estações da rede nacional de radiodifusão irradiarão, simultaneamente, programas nacionais, e, isolada ou simultaneamente, programas regionais”.

Outro aspecto que caracteriza o início das emissoras de rádio no Brasil foi o sentido de modernidade que se buscou dar com o uso do novo invento. Lia Calabre frisa que os festejos do Centenário da Independência em 1922 tinham a pretensão de mostrar um Brasil “próspero, saudável, desenvolvido, e, acima de tudo, moderno. Assim sendo, não poderia haver momento mais propício para apresentar à sociedade brasileira uma das mais recentes novidades tecnológicas que encantava o mundo: o rádio!” Modernidade, segundo Calabre, que visava romper definitivamente com o passado colonial. ${ }^{5}$

Esta busca de afirmação como nação moderna, é, para Jesus Martins Barbero, ${ }^{6}$ o eixo comum nos diferentes processos de formação dos países latino-americanos, principalmente na década de 1930. No entanto, foi uma modernidade dependente, que pressupunha a existência de mercados nacionais em função de mercados internacionais. 
Doris Fagundes Haussen mostra que a produção argentina e brasileira de equipamentos de rádio nos anos 30 com fábricas locais obedecia à lógica da industrialização substitutiva de importações. Mas essas fábricas pioneiras foram levadas à falência por conglomerados eletro-eletrônicos internacionais, que usaram técnicas de “dumping” para conquistar os mercados de bens culturais criados por estes países. Aliás, parte dos fabricantes de equipamentos eletro-eletrônicos de rádio se tornou proprietária de emissoras.

(...) em 1931, nascia a "PRAX Rádio Philips", de propriedade dos fabricantes de aparelhos elétricos (holandeses), daquela marca, "resolvidos a promover as vendas dos seus artigos no Brasil através da autopropaganda” (Tinhorão, 1981: 44). Na Argentina, em 1928, os proprietários da firma Telefuken Service adquiriam a emissora LOJ Federal Broadcasting, que passava a se chamar LOJ Telefunken Service, (.... ${ }^{7}$

O decreto-lei 21.111, de 1932, regulamentou o decreto 20.047 e autorizou a publicidade nas rádios brasileiras. Os anúncios não podiam exceder dez por cento do tempo da programação radiofônica. Assim, as emissoras passaram a faturar mais e, conseqüentemente, a diversificar os programas, que se tornaram mais populares. Alguns tiveram, incorporado no nome, a marca do patrocinador. Mas as rádios continuavam sob tutela estatal, dependendo de concessões governamentais para explorar o serviço em caráter provisório.

A Primeira Conferência Internacional Broadcasting, realizada em Washington em 1927, contabilizou no mundo 1.127 emissoras de rádio. Eram 823 na América do Norte, sendo 695 somente nos Estados Unidos. A Europa tinha 196 estações. A Oceania, 28. A África, 09. E a América do Sul, 52 estações. No final da década de 20, a Argentina tinha 36 emissoras e o Brasil, 19. As rádios européias eram predominantemente exploradas por governos ou concessionários. As das Américas, por particulares.

Em nível mundial, o desenvolvimento tecnológico possibilitou que as emissoras de rádio se consolidassem nas décadas de 1930 e 1940 enquanto veículos de comunicação de massa. Conseqüentemente, a programação radiofônica passou a ser usada das mais diversas maneiras, para os mais variados fins. "Pelo Estado; por guerras de independência e resistência; por partidos políticos e sindicatos; por movimentos sociais, religiosos e ecológicos. Seu papel político é inegável, seja qual for sua orientação". 8 
Em 1929 a União Soviética começou a transmitir programas regulares de rádio nas línguas alemã e francesa e, a partir de 1930, em inglês e neerlandês. A intenção dos soviéticos era a de difundir pelo mundo a Revolução Russa de 1917. Até a Igreja Católica se apropriou da mesma conduta. Em 1931 o poder papal criou a poliglota rádio Vaticana. A partir de 1935 o fascismo italiano passou a difundir programação na língua árabe para a África e o Oriente Médio. Durante a guerra civil espanhola, em 1936, o rádio foi usado estrategicamente pelos dois contendores com transmissões em línguas estrangeiras.

No mundo, um dos usos mais freqüentes das emissoras de rádio nos anos de 1930 e 1940 foi o da internacionalização da propaganda governamental. ${ }^{9}$ Nas mãos de líderes populistas e de ditadores, o rádio passou a ser um duplo instrumento de poder. Internamente foi usado como mecanismo cultural para se formar e fortalecer uma certa idéia de nação. Externamente, como uma máquina de propaganda para dominar corações e mentes em novos territórios.

Esses políticos buscavam convencer multidões com discursos anticapitalistas e antioligárquicos, propondo mudança e modernização da sociedade. Mas queriam apenas a legitimação e ampliação do poder que detinham e concentravam. O nazista Adolph Hitler e o fascista Benito Mussolini foram os expoentes destas condutas.

O maior desenvolvimento da internacionalização da propaganda governamental via rádio ocorreu com as ações da política externa do poder nazista alemão, baseado na guerra psicológica. Em 1933 surgiu na região de Berlim a emissora Zeesen. Ela começou a transmitir em ondas curtas em alemão - para os inúmeros grupos populacionais que haviam migrado da Alemanha - e em inglês, porque atingia os Estados Unidos.

Em 1936, durante os Jogos Olímpicos de Berlim, a rádio Zeesen irradiou programas em 28 línguas, inclusive o português do Brasil. O ministro da propaganda alemão, Paul Joseph Goebells, chegou a dizer certa vez que Adolph Hitler era inconcebível sem o uso rádio. ${ }^{10}$

Houve alguns esforços em vão na tentativa de barrar a propaganda política via rádio. Em 1934, o chanceler social-cristão da Áustria, Englebert Dollfus, decretou a interferência na freqüência dos sinais. Mas logo em seguida foi assassinado pelos nazistas. Em 1936 foi assinada em vão a primeira convenção de não-agressão radiofônica entre os membros da Sociedade das Nações. Em 1925 havia sido criada a 
União Internacional de Radiodifusão. Durante a Segunda Guerra Mundial esta foi única instituição internacional continuou funcionando, mas sem poder de influência e controlada exclusivamente pela Alemanha.

Tardiamente, Inglaterra e Estados Unidos perceberam a importância da rede de propaganda nazista via rádio. Então, em 1938, o conglomerado de comunicação estatal da Grã-Bretanha BBC reforçou o papel de combater as potências do Eixo com emissões em 23 idiomas, entre os quais o alemão, espanhol e português do Brasil.

Ainda em 1938 a Casa Branca "começa a mobilizar as redes de emissoras particulares dos Estados Unidos para neutralizar a crescente influência alemã nos países da América Latina onde estão instaladas importantes colônias de imigrantes particularmente ativas na propaganda dos ideais do regime hitleriano. ${ }^{11}$

Em fevereiro de 1942, os Estados Unidos criaram a rádio oficial $\mathrm{Voz} d a$ América. Ainda nos anos 40, publicações norte-americanas, como as revistas Reader's Digest e Time também começaram a circular na América Latina com o intuito de desestabilizar a influência dos países do Eixo na região.

Aqui podemos fazer uma reflexão considerando este desenvolvimento tecnológico da radiocomunicação e os significados de estado-nação. ${ }^{12}$

Por um lado, a propagação das ondas radiofônicas para além do território de origem pode ter contribuído para o rompimento do conceito de estado-nação representativo de um território contínuo, com limites e fronteiras demarcados, sem sistemas intermediários de dominação; um território que precisava apenas do consentimento prático de seus cidadãos para fiscalizar e agir militarmente. Segundo Eric Hobsbawn, esta representação de território como estado-nação vinha sendo usada a partir de 1830.

Por outro lado, houve uma sintonia entre a ação da propaganda radiofônica e a concepção de nação como um processo em expansão, de conquista de novos territórios e unificação nacional, que esteve em uso entre 1880 e 1918 quando se buscou mobilizar e influenciar cidadãos de uma determinada região evocando o patriotismo por meio de um elemento de identificação social e política, facilmente reconhecível por todos, como a língua. Língua que, entre outros usos, era transmitida pelas ondas do rádio.

Eric Hobsbawn considera os programas radiofônicos nazistas como uma das ações nacionalistas que visavam enraizar símbolos nacionais na vida cotidiana de qualquer indivíduo e, com isso, romper as divisões entre a esfera privada e local e a 
esfera pública e nacional. Conforme a periodização de Hobsbawn, entre 1918 e 1960, nação passa a significar consciência nacional ou um conjunto de lealdades políticas, um nacionalismo militante.

Já na América do Sul as emissoras de rádio não foram usadas dentro da perspectiva de expansão externa, mas dentro das próprias fronteiras do país, como discursava o presidente-ditador brasileiro Getúlio Dornelles Vargas. Segundo Jesús Martin-Barbero, o rádio latino-americano, assim como o cinema, teve, entre 1930 e 1950, a função política e ideológica de nacionalizar as massas populares.

Em alguns casos, como do rádio colombiano, os efeitos das transmissões radiofônicas passaram de uma idéia política de Nação para uma vivência, um sentimento e uma cotidianidade.

(...) A Colômbia podia ser denominada antes de 1940 mais como um ${ }^{13}$ país de países do que como uma Nação. Com as ressalvas do caso, a radiodifusão permitiu vivenciarse na Colômbia uma unidade nacional visível, uma identidade 'cultural' compartilhada simultaneamente pelos costeños, os paisas, os pastusos, os santandereanos e os cachacos.

No caso do Brasil, a partir do golpe de Estado que deu na Presidência da República em 03 de outubro de 1930, Getúlio Vargas se autodenominou legítimo defensor da nação. Para se comunicar com ela, dominá-la, integrá-la, Vargas lançou mão de instrumentos de poder. Entre os quais estavam as modernas técnicas de comunicação como o rádio e a propaganda.

O Governo Provisório getulista criou em 1931 o Departamento Oficial de Propaganda (DOP), agregado à Imprensa Nacional. O Departamento tinha, entre suas atividades principais, a elaboração de um programa oficial radiofônico, precursor da Hora do Brasil, que era retransmitido para o país a partir da capital federal, Rio de Janeiro.

Em julho de 1934, o DOP passou a ser chamado de Departamento Nacional de Propaganda e Difusão Cultural (DNPC) - posteriormente, apenas Departamento Nacional de Propaganda (DNP). O DNPC ficou subordinado ao Ministério da Justiça, que passou a controlar a propaganda, o rádio e o cinema. Assim, as técnicas de comunicação passaram a ser estudadas e empregadas como instrumentos de propaganda do governo getulista para obter o máximo de colaboração dos cidadãos. 
Nos anos 30, assessores políticos de Vargas e empresários de comunicação brasileiros, como Assis Chateaubriand, visitaram o III Reich. Ficaram impressionados com o controle social da população alemã a partir do emprego de técnicas de propaganda, inclusive pelo rádio. Em 22 de setembro de 1934, o assessor presidencial Luiz Simões Lopes, em visita oficial à Alemanha, recomendou a Getúlio Vargas a criação no Brasil de um órgão similar ao Ministério da Propaganda nazista. Este tornava Hitler onipresente na vida dos alemães via cinema e rádio.

Em 1937, com a reforma do Ministério da Educação e Saúde, foram criados no âmbito desta pasta o Serviço de Radiodifusão Educativa e o Instituto Nacional de Cinema. Em $1^{\circ}$ de maio de 1937, numa mensagem enviada ao Congresso Nacional, em que ampliava a quantidade de emissoras de rádio do país, Getúlio defendeu uma política de acesso fácil à recepção das emissoras. Vargas chegou a escrever aos parlamentares que

(...) o governo da União procurará entender-se, a propósito, com os Estados e Municípios, de modo que mesmo nas pequenas aglomerações, sejam instalados radioreceptores, providos de alto-falantes, em condições de facilitar a todos os brasileiros, sem distinção de sexo nem de idade, momentos de educação política e social, informes úteis aos seus negócios e toda a sorte de notícias tendentes a entrelaçar os interesses diversos da nação (...). ${ }^{14}$

Em 27 de dezembro de 1939, pelo decreto-lei no 1.915, Vargas substituiu o DNP pelo Departamento de Imprensa e Propaganda (DIP). O DIP era subordinado diretamente à presidência e tornou-se um dos órgãos mais temidos na ditadura do Estado Novo. Entre as 16 funções do Departamento listadas no decreto de criação estava a de censurar os veículos de comunicação. Cabia também ao DIP fazer a propaganda do regime e de Vargas. O Departamento de Imprensa e Propaganda também tinha a finalidade de organizar e dirigir o programa de radiodifusão oficial do Governo. No decreto estava previsto que o DIP seria dotado de uma estação radiofônica e radiotelegráfica.

O projeto de uma emissora de rádio oficial - como elemento de integração nacional, difusão da cultura brasileira e propaganda política - era uma acalentado por Getúlio Vargas antes da decretação da ditadura do Estado Novo em 1937. Numa entrevista concedida à revista Voz do Rádio, em fevereiro de 1936, Lourival Fontes, 
diretor do Departamento de Propaganda e Difusão Cultural - antecessor do DIP enfatizou que o governo federal deveria ter uma rádio.

Dos países de grande extensão territorial, o Brasil é o único que não tem uma estação de rádio "oficial". Todos os demais têm estações que cobrem todo o seu território. Estas estações atuam como elemento de unidade nacional. Uma estação de grande potência torna o receptor barato e, portanto, o generaliza. (...)

Não podemos desestimar a obra de propaganda e de cultura realizada pelo rádio e, principalmente, a sua ação extra-escolar; basta dizer que o rádio chega até onde não chegam a escola e a imprensa, isto é: aos pontos mais longínquos do país e, até, à compreensão do analfabeto. ${ }^{15}$

Em 1940 a maioria da população brasileira (68,76\%) vivia em áreas rurais e 31,23\% em regiões urbanas. Neste mesmo ano havia no país quase um milhão de aparelhos receptores de rádio, a maior parte deles sintonizada em emissoras do Rio de Janeiro. Para os dirigentes da comunicação do Estado Novo, o rádio era um dos principais instrumentos para se vencer a barreira das distâncias entre as regiões brasileiras e obter a unidade nacional.

As distâncias foram sempre um dos inimigos eficientes do nosso progresso. Durante longos anos os brasileiros espalhados por todas as latitudes, que trabalhavam pela grandeza nacional, viveram um pouco esquecidos, à míngua de contatos. Com o rádio pôde o Brasil desvanecer essas dificuldades, vencendo o seu pior inimigo. ${ }^{16}$

Ainda 1936, o Ministério da Educação e Saúde ganhou gratuitamente de Roquette Pinto o canal da pioneira Sociedade Rádio do Rio de Janeiro (hoje rádio MEC AM do Rio de Janeiro). O presente teve um preço para o Governo Federal: “(...) não utilizar a emissora para outros fins senão o de desenvolvimento da cultura popular e jamais permitir a publicidade comercial ou a propaganda política” ${ }^{17}$ Desta forma a emissora ficou subordinada ao ministro da Educação, Gustavo Capanema, e não a Francisco Campos, ministro da Justiça, que pretendia usá-la exclusivamente como meio de propaganda.

Então, em 08 de março de 1940, três meses após a criação do DIP, outro decreto-lei da ditadura getulista, o 2.073, efetivou a criação de uma rádio oficial. Entre as empresas incorporadas ao patrimônio da União, estavam o jornal A Noite, a Rio Editora e a Rádio Nacional. Esta emissora carioca, com dois transmissores de ondas 
curtas, era captada na maior parte do Brasil e em países da América do Norte, Europa e África. A Nacional foi transformada no principal palco para músicos e artistas de radionovelas. Mas, sob as diretrizes do Estado Novo e dos interesses nacionais impostos pela ditadura.

Num programa transmitido no feriado nacional da Independência, Vargas assegurou à nação que a liberdade chegara ao país por intermédio da “democracia funcional” do Estado Novo. Já o ministro do Trabalho, Alexandre Marcondes Filho, utilizava toda quinta-feira dez minutos do programa radiofônico oficial Hora do Brasil cuja retransmissão em cadeia nacional de emissoras era obrigatória - para falar aos trabalhadores. Estes, para a ditadura getulista, "estavam fabricando um Brasil novo, com mais direitos, mais justiça social e mais dignidade humana”. ${ }^{18}$

A ditadura getulista se apropriou da programação das emissoras para atingir e estimular a imaginação dos ouvintes. A meta era despertar nos brasileiros o sentimento de comunidade, de participação na construção da nação, de identidade nacional. $O$ período ditatorial do Estado Novo também criou o mito Vargas. O culto à personalidade do chefe da Nação - em livros para crianças, fotos, filmes, festividades, cerimônias oficiais, músicas e programas de rádio - era uma maneira de substituir as liberdades políticas. ${ }^{19}$ Para Alcir Lenharo,

O rádio permitia uma encenação de caráter simbólico e envolvente, estratagemas de ilusão participativa e de criação de um imaginário homogêneo de comunidade nacional. O importante do rádio não era exatamente o que era passado e sim como era passado, permitindo a exploração de sensações e emoções propícias para o envolvimento político dos ouvintes. ${ }^{20}$

Mas é importante salientar que - tanto no Governo Provisório (1930-1937), quanto na ditadura do Estado Novo (1937-1945) - não havia um projeto único para o setor de radiodifusão. Tanto que a legislação para funcionamento das estações radiofônicas tinha como efeito um sistema misto. Havia o controle estatal. O governo federal dava o direito de concessão para quem ele quisesse. Mas o uso do canal, como hoje, tinha caráter provisório, podendo ser renovado ou não. Dependia do comportamento do dono da emissora perante as exigências e fiscalização do governo.

A mesma legislação permitia a publicidade comercial durante a programação radiofônica. Assim, havia um sentimento de "liberdade” de ação para os donos das rádios. Conseqüentemente, o conteúdo dos programas oscilou ao sabor das novidades e 
apelos da concorrência, da preferência cultural da audiência popular, dos interesses dos patrocinadores, inclusive estrangeiros, e das orientações governamentais.

Na década de 1940, principalmente após a decisão do Brasil de apoiar os países aliados na Segunda Guerra Mundial em agosto de 1942, as rádios brasileiras ficaram à mercê das agências de publicidade norte-americanas e da cultura anglo-saxã, imposta pelas marcas patrocinadoras dos programas. O Repórter Esso, patrocinado por uma empresa petrolífera norte-americana, passou a divulgar, a partir de 1941, notícias do conflito na ótica dos Estados Unidos a partir da Rádio Nacional.

Além do interesse comercial, o conteúdo da programação radiofônica nos anos 30 e 40 no Brasil ainda tinha de veicular a propaganda política de Getúlio Vargas. Por um lado, esta comunicação governamental tinha certas características da propaganda nazista, como a transmissão dos discursos presidenciais, a subordinação direta do DIP a Vargas, a obrigatoriedade da retransmissão da Hora do Brasil em rede nacional de emissoras e a existência da emissora oficial Rádio Nacional.

Por outro lado, havia um projeto educativo-cultural para o rádio. Este possuía traços menos explícitos de propaganda política, mas defendia o governo de Getúlio Vargas nas músicas selecionadas, nas histórias heróicas relatadas, ou nos públicos ouvintes escolhidos, como os apelos aos trabalhadores e a radiodifusão escolar para crianças.

Durante o Estado Novo, o controle dos conteúdos radiofônicos ficou dividido. O diretor do DIP, Lourival Fontes, controlava a Hora do Brasil. O ministro do Trabalho, Alexandre Marcondes Filho, comandava um programa semanal dentro da Hora. A radiodifusão educativa estava sob a orientação do ministro da Educação, Gustavo Capanema. E o Departamento de Divulgação Político-cultural da Rádio Nacional ficou a cargo do intelectual Cassiano Ricardo, o ideólogo da Marcha para Oeste.

Para José Inácio de Melo Souza, o receio da ditadura Vargas de fazer uso de um meio tão poderoso de mobilização popular explica essa fragmentação do rádio em ações isoladas. ${ }^{21}$

Esta participação dispersa dos órgãos governamentais na rede radiofônica nacional, em prejuízo de uma orientação mais unificada e harmoniosa, foi reconhecida tardiamente pelos estado-novistas. Em outubro de 1944, Getúlio Vargas aprovou a criação uma comissão para analisar a radiodifusão e apresentar um projeto de Código do Rádio que atendesse os aspectos técnicos, administrativos e políticos da radiofonia 
brasileira. A meta era a elaboração de uma legislação especial, para que o rádio pudesse cumprir melhor a missão de trabalhar pela unidade política e espiritual do nosso país. ${ }^{22}$

Maria Helena Rolim Capelato afirma que Getúlio Vargas não tinha interesse em mobilizar as massas para participar da vida política do Brasil, pois o autoritarismo do Estado Novo era desmobilizador. Na visão estado-novista, o povo brasileiro era inepto para a participação política. A preocupação da ditadura era de buscar o apoio das elites intelectuais leitoras de jornais e livros, e não das massas de ouvintes do rádio. Talvez, por isso, a imprensa tenha sido mais censurada e comprada. Enquanto isso, o rádio foi mais usado para divulgação cultural e a propaganda.

Barbero analisa os meios massivos pela ótica da recepção, buscando o lugar onde se articula o sentido, ou seja, no caso dos meios massivos, os processos culturais enquanto articuladores de práticas de comunicação - hegemônicas e subalternas - com os movimentos sociais. ${ }^{23}$ Inspirado por esta perspectiva de análise - focada na produção de sentido na recepção da mensagem, quero concluir focalizando alguns problemas enfrentados pelos programas radiofônicos oficiais brasileiros nos anos de 1930 e 1940 .

Doris Fagundes Haussen mostra que o programa oficial Hora do Brasil, criado em 1935 para divulgar as ações de governo getulista, passou a partir de 1937 a ter retransmissão obrigatória em rede nacional de rádio, todos os dias úteis, no horário nobre da época: das 18h45 às 19h30, em ondas médias e curtas, e das 19 h30 às 19h45, somente em ondas curtas.

Mas a escuta do programa era boicotada por parte dos ouvintes, que o apelidaram de Fala Sozinho. Em contrapartida, o governo publicava no jornal oficial $A$ Manhã enquetes favoráveis ao programa feitas nas ruas. Algumas rádios do interior que não retransmitiam a Hora do Brasil, até mesmo por falta de condições técnicas, eram denunciadas a altos dirigentes do governo federal, como Filinto Müller, por colaboradores do regime espalhados pelo Brasil. ${ }^{24}$

Também havia problemas na recepção. Em agosto de 1939, no recém-criado jornal O Estado de Mato Grosso, fora publicado o artigo Rumo Oeste. O texto defende a constituição de uma emissora de rádio com irradiação a partir da capital federal e com captação no país inteiro. A justificativa era a exigência do ideário da política varguista, de expansão do Brasil dentro das próprias fronteiras. Como a Marcha para Oeste. ${ }^{25}$

O artigo "Rumo Oeste” reclama da dificuldade de captação de sinais das rádios instaladas no Rio de Janeiro que transmitiam programas oficiais do governo federal. O 
texto também pede providências diante da facilidade de sintonia das rádios argentinas em Cuiabá.

\begin{abstract}
Rumo Oeste
O brado vitorioso do Sr. Getulio Vargas, da marcha para o Oeste, imprimindo novos rumos às velhas e lendárias bandeiras, está a exigir, primacialmente, a organização de uma transmissora de rádio, em ondas curtas e longas, que deveria funcionar permanentemente, na capital da Republica, com a potência necessária para atingir com vantagem, os mais longínquos recantos do país.

Seria colocar todos os núcleos de população esparsos por todo o vasto território brasileiro ao alcance da voz do Brasil, durante todo o dia e, não apenas nos poucos instantes reservados à "hora nacional".

Seria, sobretudo, como obras de nacionalismo, evitar se vissem os brasileiros do extremo Oeste obrigados a manter seus rádios sintonizadas, durante todo o dia, em estações estrangeiras, notadamente argentinas, que são as que mantêm irradiação permanente em ondas curtas...

Talvez se ignore no Rio e S. Paulo que as transmissões em ondas longas e médias das estações nacionais somente à noite são ouvidas em Mato Grosso e que, estamos, nessas condições, debaixo da influência Argentina.

As transmissões dos programas esportivos, culturais e artísticos, da capital federal, que não se realizam à noite, quando não patrocinados pela estação de ondas curtas do Departamento Nacional de Propaganda deixam de ser feitas "para o Brasil inteiro", como aprogôam (sic) os speakers, mas somente para os Estados vizinhos da capital da República.

Que se faça, do rádio, no Brasil, um fator de nacionalização e o pioneiro do "Rumo ao Oeste”. Poderoso instrumento de propaganda, constitui ele, no século em que vivemos, o elo mais forte de aproximação e a força mais viva de realização no campo espiritual e político-social.
\end{abstract}

A preocupação com a potência das emissoras argentinas não era só matogrossense. Mesmo no Rio de Janeiro admitia-se uma inferioridade de potência entre as estações brasileiras e rádios da Argentina e Uruguai. Em 19 de setembro de 1935, foi publicado um artigo com este teor, na revista Voz do Rádio, pelo seu diretor, Gilberto

Goulart de Andrade.

Várias vezes têm-se comentado a situação de inferioridade potencial das estações nacionais em relação com as argentinas e uruguaias, do que decorrem evidentes prejuízos para a divulgação cultural e o serviço de informações e a propaganda do país. Este ano, felizmente, houve sensível melhoria, com o advento da Rádio Jornal do Brasil (10 quilowatts), Rádio Ipanema (5 quilowatts), Farroupilha (25 quilowatts) e Tupi (10 quilowatts). A Mayrink, Guanabara e Philips dentro de pouco tempo estarão também com os seus transmissores remodelados ou ampliados. ${ }^{27}$

Nestes processos de invenção da tecnologia radiofônica e criação, desenvolvimento e uso do conteúdo das emissoras de rádio - entre meados do século 
XIX e a primeira metade do XX - vejo dois binômios. Um é físico, material. Ocorreu tanto com a expansão territorial das nações, quanto com a propagação das ondas radiofônicas.

O outro binômio é cultural, imaterial. O discurso radiofônico difundiu propaganda política para dominar corações e mentes. Tanto para conquistar novos territórios, quanto para integrar a nação. Como também para legitimar o poder populista ou ditatorial.

\section{NOTAS}

* Texto apresentado no Seminário Identidades Nacionais e Integração na América Latina, na UFMT, Cuiabá, em 19/11/2003.

** Antonio Carlos Silva é mestrando no Programa de Pós-Graduação em História da UFMT. Sob orientação do professor doutor Otávio Canavarros, pesquisa a emissora de rádio A Voz do Oeste, de Cuiabá, nos anos de 1939 e 1949.

1 TINHORÃO, José Ramos. Música Popular, do gramofone ao rádio e TV. São Paulo: Ática, 1981.

2 MATTELART, Armand. A globalização da comunicação; tradução Laureano Pelegrin. Bauru: EDUSC, 2000, p. 33.

3 Trecho do ofício enviado pela ABE ao presidente do Estado de Mato Grosso, em 29/08/1925. Acervo do Arquivo Público de Mato Grosso, lata ano 1925, pasta Correspondência enviada ao presidente do Estado apud MÜLLER, Lúcia. As construtoras da nação: professoras primárias na Primeira República. Niterói: Intertexto, 1999, p. 66.

4 NUNES, Márcia Vidal. Rádio e política: do microfone ao palanque: os radialistas políticos em Fortaleza (1982-1996). São Paulo: Annablume, 2000, p. 51.

5 CALABRE, Lia. A era do rádio. Rio de Janeiro: Zahar, 2002, p. 10.

6 MARTÍN-BARBERO, Jesús. Dos meios às mediações: comunicação, cultura e hegemonia. Rio de Janeiro: Editora UFRJ, 2003.

7 HAUSSEN, Doris Fagundes. Rádio e política: tempos de Vargas e Perón. Porto Alegre: EDIPUCRS, 2001, $2^{\text {a }}$ edição, p. 26.

8 Idem, p. 11.

9 MATTELART, op. cit., p. 81.

10 ORTRIWANO, Gisela Swetlana. A informação no rádio: os grupos de poder e a determinação dos conteúdos. São Paulo: Summus, 1985. p. 60.

11 MATTELART, op. cit., pp. 83-4.

12 Recorro aos conceitos formulados por HOBSBAWN, Eric. Nações e nacionalismo desde 1780: programa, mito e realidade. Rio de Janeiro: Paz e Terra, 1990, e CHAUÍ, Marilena. Mito fundador e sociedade autoritária. São Paulo: Ed. Fundação Perseu Abramo, 2001.

13 MARTÍN-BARBERO, Jesús. Op. cit, p. 242. Nesta passagem, o autor se apóia em PAREJA, R. Historia de la radio en Colombia. Bogotá: Servicio Colombiano de Comunicación Social, 1984. 
14 HAUSSEN, op. cit., p. 40.

15 Depoimento do diretor do Departamento de Propaganda e Difusão Cultural (o DIP foi criado em 27/12/1939), Lourival Fontes, a Jayme Távora, redator da revista Voz do Rádio, no 40, de 20 fev. 1936. In: SAROLDI, Luiz Carlos \& MOREIRA, Sonia Virgínia. Rádio Nacional: o Brasil em sintonia. Rio de Janeiro: Martins Fontes/Funarte, 1988, 2ª edição, p. 13.

16 Discurso do diretor geral do DIP, Lourival Fontes, na inauguração dos novos estúdios da Rádio Nacional, em 19 de abril de 1942. In: SAROLDI, Luiz Carlos \& MOREIRA, Sonia Virgínia, op. cit., epígrafe.

17 LOPES, Saint-Clair. Comunicação radiofônica hoje. Rio de Janeiro: Temário, 1970, p. 33 apud HAUSSEN, op. cit., p. 18.

18 LEVINE, Roberto M. Pai dos pobres? O Brasil e a era Vargas. São Paulo: Companhia das Letras, 2001. p. 96.

19 D’ARAUJO, Maria Celina. A Era Vargas. São Paulo: Moderna, 1997, p. 93.

20 LENHARO, Alcir. Sacralização da política. Campinas: Papirus, 1986, pp. 40-1.

21 MELO SOUZA, José Inácio de. A ação e o imaginário de uma ditadura: controle, coerção e propaganda política nos meios de comunicação durante o Estado Novo. São Paulo: USP, 1990, dissertação de mestrado apud FREITAS, Marcos Cezar de (org.) Historiografia Brasileira em Perspectiva. São Paulo: Contexto/Universidade São Francisco, 1998, p. 206.

22 Ofício DG-748, de 19/10/1944, exposição de motivos do diretor geral do DIP, Amílcar Dutra de Menezes, ao presidente Getúlio Vargas, publicada no Diário Oficial da União de 27/10/1944, p. 18.488.

23 MARTÍN-BARBERO, op. cit., p. 241.

24 Estes relatos podem ser encontrados no Arquivo Filinto Müller, no CPDOC/FGV.

25 A Marcha para o Oeste foi um projeto político elaborado por intelectuais estado-novistas que se apropriou da memória do bandeirantismo colonial brasileiro para dar sentido a uma nova exploração das riquezas do país, principalmente dos minérios das regiões amazônica e oeste. Era o Brasil em movimento, "a imagem da Nação que caminha pelas próprias forças em busca de sua concretização". (LENHARO, op. cit, p. 56).

26 O Estado de Mato Grosso, edição no 3, 29/08/1939, p. 2. Acervo microfilme NDHIR/UFMT. O dono do jornal O Estado de Mato Grosso era o jornalista Archimedes Pereira Lima. Em 1939 ele presidia a Imprensa Oficial do Estado, na interventoria federal de Júlio Müller. A partir de 1943, dirigiu o Departamento Estadual de Imprensa e Propaganda (DEIP), o braço mato-grossense do DIP.

27 SAROLDI et al, op. cit., p. 12. Gilberto Goulart de Andrade dirigiu a revista Voz do Rádio até 1936, ano em que assumiu o cargo de procurador no Tribunal de Segurança Nacional. Em 1940, foi o primeiro diretor da Rádio Nacional, recém-encampada pelo Governo Federal. 